\title{
DETECTION OF HIV AND HCV RNA IN SEMEN FROM BRAZILIAN COINFECTED MEN USING MULTIPLEX PCR BEFORE AND AFTER SEMEN WASHING
}

\author{
Cynthia Liliane Motta do CANTO(1), Aluisio C. SEGURADO(1), Cláudio PANNUTI(1), Agnaldo CEDENHO(2), Miguel SROUGI(2), Deborah SPAINE(2), \\ Silvana FERNANDES(1), Nadily CARRETIERO(1), Maria Carolina BERNAL(1) \& José Eduardo LEVI(1)
}

\begin{abstract}
SUMMARY
Introduction. Prolonged survival of patients under HAART has resulted in new demands for assisted reproductive technologies. HIV serodiscordant couples wish to make use of assisted reproduction techniques in order to avoid viral transmission to the partner or to the newborn. It is therefore essential to test the effectiveness of techniques aimed at reducing HIV and HCV loads in infected semen using molecular biology tests.

Methods. After seminal analysis, semen samples from 20 coinfected patients were submitted to cell fractioning and isolation of motile spermatozoa by density gradient centrifugation and swim-up. HIV and HCV RNA detection tests were performed with RNA obtained from sperm, seminal plasma and total semen.

Results. In pre-washing semen, HIV RNA was detected in 100\% of total semen samples, whereas HCV RNA was concomitantly amplified in only one specimen. Neither HIV nor HCV were detected either in the swim-up or in the post-washing semen fractions.

Conclusions. Reduction of HIV and/or HCV shedding in semen by density gradient centrifugation followed by swim-up is an efficient method. These findings lead us to believe that, although semen is rarely found to contain $\mathrm{HCV}$, semen processing is highly beneficial for HIV/HCV coinfected individuals.
\end{abstract}

KEYWORDS: HIV; HCV; Coinfection; Serodiscordant couples; Semen washing; Swim-up.

\section{INTRODUCTION}

According to current figures in the Brazilian Epidemiological Reports (www.aids.gov.br), there are 600,000 HIV-infected people in Brazil, of whom $65 \%$ are males of sexually active age. Also worthy of note is the growing proportion of Brazilians (17.7\% to $36.2 \%$ ) who are also infected with the hepatitis $\mathrm{C}$ virus $(\mathrm{HCV})^{25,40}$. This coinfection is an important factor in the natural history of AIDS and contributes to greater morbidity and mortality in these patients. Furthermore, prolonged survival of patients under HAART (Highly Active Antiretroviral Therapy) has given rise to a new demand from serodiscordant couples who wish to have children. As these couples cannot stop using condoms, lest they infect their seronegative partner or the newborn, it is essential to treat the infected semen with effective laboratory techniques that not only isolate the best spermatozoa, but also remove HIV and HCV infected cells from the semen.

This is achieved in many studies by using the semen washing technique together with the swim up ${ }^{26}$ method to purify the infected semen $^{17,18,24,32}$.

These techniques are currently in widespread use in different parts of the world ${ }^{29,30,41,43}$. Some authors, however, question this type of procedure and raise doubts as to its effectiveness in removing HIV from sperm ${ }^{1,2,3,37}$. There are still questions regarding the possible passive transport of the virus from the systemic compartment to the genital $\operatorname{tract}^{23}$. Several studies report both a limited relationship between blood plasma and seminal-HIV viral load, as well as the presence of phylogenetically different strains in both. They also report possible intermittent excretion of HIV in semen, whereas in blood the viremia persists during all stages of the disease ${ }^{16}$, even during HAART ${ }^{27,35}$. Nevertheless, a small fraction of HIV carriers remain asymptomatic after years of infection, with a CD4+ cell count of over $500 \mathrm{~mm}^{3}$ and undetectable viral load, even without any treatment ${ }^{4,6,10,46}$. These patients are designated long-term nonprogressors (LTNPs) ${ }^{7}$.

The risk of hepatitis $\mathrm{C}$ transmission in assisted reproduction techniques is currently the subject of widespread debate ${ }^{11,22,33}$. LEVY et al. investigated the presence of HCV RNA in the semen of infected men in order to find out if semen fractions act as a reservoir for the hepatitis C virus. In their study, HCV RNA was found in 2/39 (5\%) of semen and semen fraction samples, giving direct evidence of the risk of contamination that may exist in human reproduction techniques ${ }^{22}$. Other studies concluded that although the presence of HCV in semen 


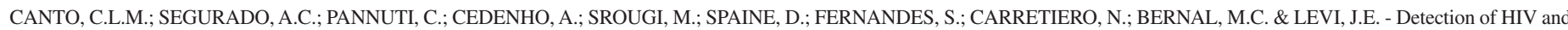
HCV RNA in semen from Brazilian coinfected men using multiplex PCR before and after semen washing. Rev. Inst. Med. trop. S. Paulo, 48(4): 201-206, 2006.

is intermittent ${ }^{31}$ and not common ${ }^{13,15}$, sexual transmission cannot be ruled out ${ }^{20,34}$.

In contrast, both recent and earlier studies concluded that purification of motile spermatozoa by either the discontinuous gradient or swim-up method, or even by a combination of these techniques, reduces the number of $\mathrm{HIV}$ and/or $\mathrm{HCV}$ particles in semen to undetectable levels ${ }^{8,14,17,18,24,28,32}$, making it possible for serodiscordant couples to conceive a child by means of assisted reproduction techniques with minimum risk of seroconversion ${ }^{14,15,32}$.

Although there are a large number of studies regarding the transmission of HIV and/or HCV through assisted reproduction techniques, the findings differ and are to a certain extent in conflict with each other, thus reinforcing the need for further investigation using molecular biology tests.

\section{OBJECTIVE}

This study set out to evaluate the effectiveness of density gradient centrifugation and swim-up techniques in reducing HIV and HCV loads in infected semen, using molecular biology tests for viral detection.

\section{MATERIAL AND METHODS}

1. Population selection: Between January 2003 and May 2004, semen was collected from a convenience sample of $20 \mathrm{HIV} / \mathrm{HCV}$ coinfected patients in the 27- to 45-year age range who had undetectable plasma viral loads for HIV, were positive for HCV RNA in blood (by RT- PCR) and for anti-HCV (by ELISA), and who had presented at the Human Reproduction Section of the Federal University of São Paulo for assisted reproduction screening. Patients who had undergone vasectomy, had azoospermia or referred a symptomatic Sexually Transmitted Disease (STD) at enrolment were excluded from the study. The investigation protocol was approved by the Institutional Review Board.

2. Semen collection and processing: Samples were collected by masturbation into a sterile polypropylene flask after three to five days of ejaculatory abstinence. After liquefaction and homogenization, the seminal sample was divided into two aliquots. The first aliquot was initially submitted to semen analysis according to the World Health Organization (WHO) guidelines ${ }^{48}$. Following semen analysis, the aliquot was submitted to semen processing using a discontinuous Percoll $^{\circledR}$ (Pharmacia, Sweden) gradient technique at two different concentrations $(90 \%$ and $45 \%)$. After centrifugation (110 g, 30 minutes), three different fractions were obtained: seminal plasma, dead sperm and cellular elements other than sperm (germ line cells, cellular debris, bacteria and leukocytes), and motile spermatozoa.

The second aliquot (total semen) was stored in a $-70{ }^{\circ} \mathrm{C}$ freezer and used later in parallel with seminal fractions in our search for HCV and HIV genital shedding. For this purpose, $100 \mu \mathrm{L}$ of total semen and of the three fractions obtained by the discontinuous gradient technique were used for RT PCR multiplex amplification of HCV and HIV sequences before semen washing.

The remaining volume of each fraction (approximately $900 \mu \mathrm{L}$ ) was washed three times with RPMI and the cell pellet resuspended in $1 \mathrm{~mL}$ of medium. The fraction containing motile spermatozoa was further submitted to the swim-up method ${ }^{26}$. The best motile sperm that migrated to the culture medium were then carefully removed.

All samples (positive control, total semen and seminal fractions) were then submitted to nucleic acid extraction using the Nuclisens ${ }^{\circledR}$ kit (Biomérieux, Brazil) according to the manufacturer's instructions. Nucleic acids were eluted in $50 \mu \mathrm{L}$ of a specific buffer ${ }^{9}$ and stored at $-70{ }^{\circ} \mathrm{C}$ until qualitative pre- and post-semen-washing RT-PCR viralsequence amplification was performed. This test was carried out using $100 \mu \mathrm{L}$ of each pre- and post-semen washing aliquot.

\section{HIV and HCV Multiplex RT-PCR}

3.1 cDNA synthesis: Complementary DNA (cDNA) was synthesized using a reaction mixture that contained 1x RT Buffer, 0.2 mM dNTPs (dATP, dTTP, dCTP, dGTP), 4.0 mM MgCl, 40 IU RNAsin, 103M DTT, $2.5 \mu \mathrm{M}, \mathrm{PDN}(6) 2.5 \mathrm{U}, \mathrm{M}-\mathrm{MLV}$ RT and $22.0 \mu \mathrm{L}$ of extracted RNA in a total volume of $40 \mu \mathrm{L}$, following a standardized protocol $\left(65^{\circ} \mathrm{C}\right.$ for five $\min , 22^{\circ} \mathrm{C}$ for $10 \mathrm{~min}, 37^{\circ} \mathrm{C}$ for $30 \mathrm{~min}$ and $95^{\circ} \mathrm{C}$ for five $\min )$.

3.2 HIV/HCV Multiplex RT-PCR: Ten microlitres of cDNA were then submitted to a qualitative multiplex RT-PCR technique, in which three viral genome sequences ( $\mathrm{HIV}^{38}, \mathrm{HCV}$ and Dengue type 1 virus) were simultaneously amplified using specific primer pairs for each viral agent.

Multiplex RT-PCR amplification was performed in total semen as well as in the spermatozoa and dead-sperm and nonspermatozoa seminal fractions using a reaction mixture that contained 1x Buffer, $0.12 \mathrm{mM}$ dNTPs (dATP, dTTP, dCTP and dGTP), $2.0 \mathrm{mM} \mathrm{MgCl}_{2}, 1.25 \mathrm{U}$ of AmpliTaq Gold® (Applied Biosystems, Foster City, Ca, USA) in $40 \mu \mathrm{L}$ total volume. The following amplification protocol was used: one cycle at $95{ }^{\circ} \mathrm{C}$ for five minutes followed by 40 cycles consisting of

Table 1

Specific primer pairs used for multiplex RT-PCR amplification of viral genome sequences in seminal samples

\begin{tabular}{lll}
\hline HIV & RAR 1032 & 5'GAG ACA CCA GGA ATT AGA TAT CAG TAC AAT GT3' \\
& RAR 1033 & 5'CTA AAT CAG ATC CTA CAT ATA AGT CAT CAT GT3' \\
HCV & SM3 & 5'CTA GCC ATG GCG TTA GAT3' \\
Dengue & HC18 & 5'GGT GCA CGG TCT ACG AGA CCT3' \\
& D1 & 5' TCA ATA TGC TGA AAC GCG GGA GAA ACC G3' \\
& TS1 & 5'CGT CTC AGT GAT CCG GGG G3'
\end{tabular}


30 seconds at $94{ }^{\circ} \mathrm{C}, 30$ seconds at $55^{\circ} \mathrm{C}$ and one minute at $65^{\circ} \mathrm{C}$, and a final 7-minute extension at $65{ }^{\circ} \mathrm{C}$ in an automated thermal cycler.

To validate the nucleid-acid extraction and the RT-PCR amplification steps, $10 \mu \mathrm{L}$ of serum known to be infected by the Dengue I virus were added to each sample as an internal reaction control. We used a $100 \mu \mathrm{L}$ mix containing $10 \mu \mathrm{L}$ of $\mathrm{HCV}$-positive $(774,892$ viral copies/mL) and $10 \mu \mathrm{L}$ of HIV-positive $(1,700,000$ viral copies/mL) sera, $10 \mu \mathrm{L}$ of Dengue I virus culture supernatant and $70 \mu \mathrm{L}$ of $\mathrm{HCV}$, HIV and dengue-negative serum as a positive control for the HIV/ $\mathrm{HCV}$ multiplex RT-PCR reaction. Analytic sensitivity is $500 \mathrm{UI} / \mathrm{mL}$ for both viruses (José Eduardo Levi, personal communication).

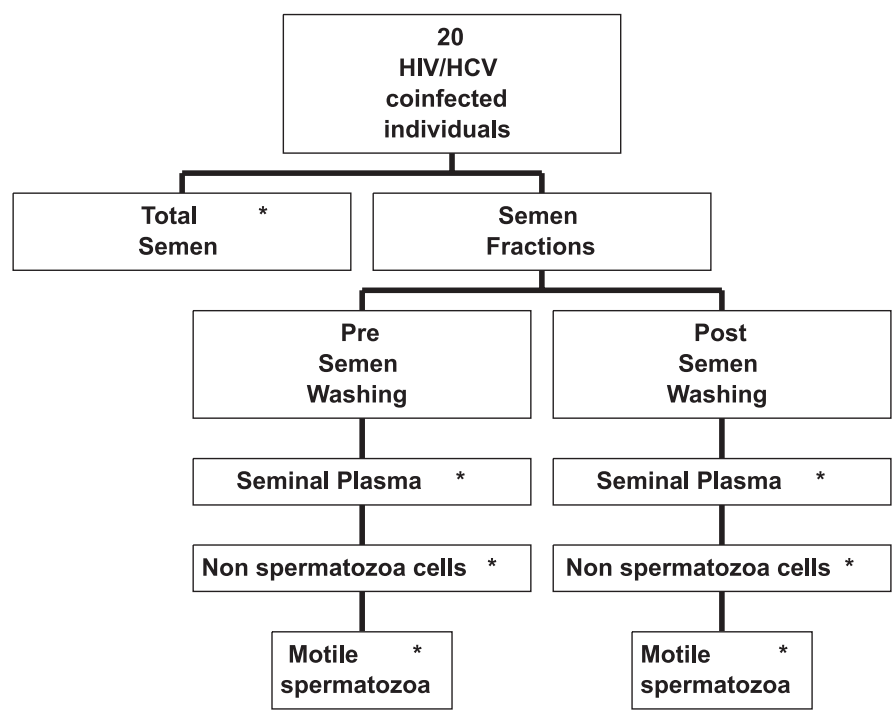

* Specimen submitted to multiplex RT - PCR with spiked Dengue - 1 RNA virus.

Fig. 1 - Flowchart of protocol design using multiplex PCR before and after semen washing.

After electrophoresis, RT-PCR amplification products were visualized under ultraviolet light on $2 \%$ agarose gels stained with ethidium bromide.

\section{RESULTS}

Each patient provided one seminal sample that was used for seven different HIV/HCV multiplex RT-PCR tests (total semen in the prewashing phase; seminal pre and post-washing phases). A total of 140 multiplex RT-PCR reactions were performed on semen samples collected from twenty HIV/HCV-coinfected patients.

In the pre-washing phase HIV RNA was detected in $100 \%$ of totalsemen samples, as well as in $50 \%$ of seminal plasma samples. HIVRNA sequences were detected in dead-sperm and non-sperm cells from six out of twenty cases (30\%) and in motile-spermatozoa fractions in one out of twenty cases (5\%). In contrast, HCV RNA was detected in only one of the 20 total-semen specimens tested.

After semen washing, neither HIV RNA nor HCV RNA could be

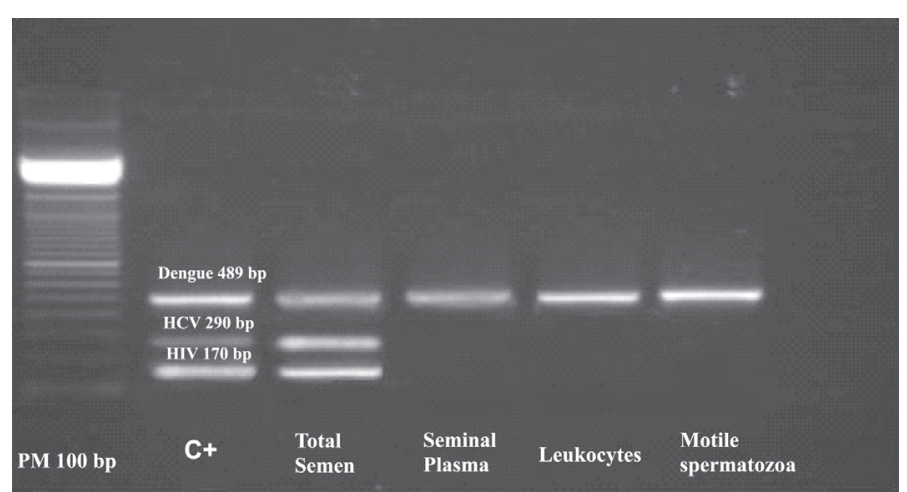

Fig. 2 - Representative sample of multiplex RT-PCR amplification of HIV and HCV genome sequence in seminal samples from Brazilian coinfected patients.

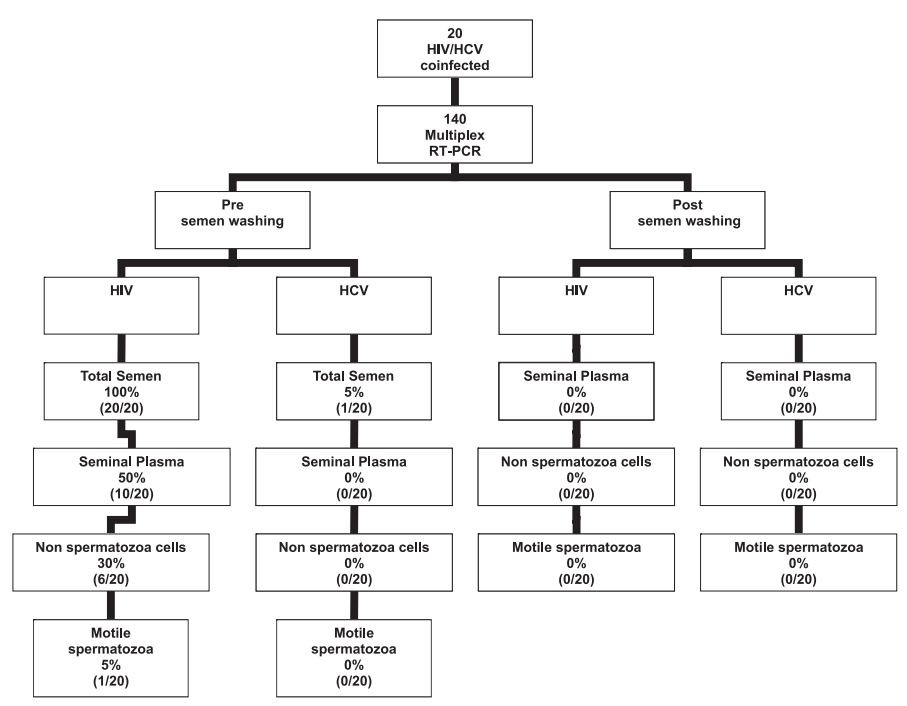

Fig. 3 - Flowchart of outcomes for detection and reduction of HIV and HCV in semen from coinfected patients before and after semen washing.

detected in any of seminal fractions. However, Dengue virus sequences were detected in all specimens, confirming the efficiency of the extraction, reverse-transcription and PCR-amplification steps.

\section{DISCUSSION}

HIV and HCV share the same transmission pathways (parenteral and sexual), and there is therefore an increased risk of coinfection, especially as the hepatitis $\mathrm{C}$ virus is ten times more infectious than HIV. HIV/HCV coinfection is a serious public health problem worldwide, and $30 \%$ of people infected with HIV are also coinfected with $\mathrm{HCV}^{39}$. There is evidence that this coinfection can change the natural history of HIV/AIDS infection by causing the number of TCD4 blood cells to decrease faster, as HCV leads to proliferation of TCD4 ${ }_{+}^{+}$ cells in hepatic tissue and promotes HIV replication ${ }^{39}$. This would especially be the case in patients with high HCV titer, due to interference in the production of cellular cytokines, causing the HIV/HCV viral load to increase even further ${ }^{47}$. 


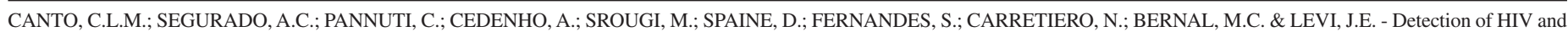
HCV RNA in semen from Brazilian coinfected men using multiplex PCR before and after semen washing. Rev. Inst. Med. trop. S. Paulo, 48(4): 201-206, 2006.

The advent of HAART, however, is also changing the natural history of $\mathrm{HIV} / \mathrm{HCV}$ coinfection because of increased patient survival ${ }^{15}$. As a result, an ever increasing number of serodiscordant couples wish to have their own child without resorting to gamete donation in sperm banks or giving up safe sex. The only option available to these couples is to seek assisted reproduction techniques associated with ultrasensitive molecular biology tests that ensure that their partner will not be contaminated or that the virus will not be transmitted horizontally or vertically.

Some studies suggest that the presence of HIV is an important cofactor in increased sexual transmission of $\mathrm{HCV}^{5,12}$. The probability of vertical transmission in female coinfected patients is always higher ${ }^{50}$ and is always associated with high viral load ${ }^{44}$.

In our study, HCV RNA was detected in the pre-semen washing phase in only one sample of total semen, suggesting that sexual transmission can occur, but that it is less frequent than HIV. These findings agree with data in the literature, where $\mathrm{HCV}$ was rarely detected in semen ${ }^{12}$, and then only intermittently ${ }^{31}$.

In contrast, there was a $100 \%$ prevalence of HIV RNA in total semen. This positivity rate confirms both the high degree of sensitivity of our multiplex PCR and the effectiveness of the HIV/HCV RNA extraction method, which eliminates possible inhibitors that could produce false-negative results.

Because our casuistic only includes patients with undetectable plasma viral load for HIV, the high prevalence of HIV RNA found in total semen can be explained by HIV compartmentalization ${ }^{16,36,44}$, as we had expected HIV not to be detected in at least some semen samples.

The fact that we found HIV in seminal plasma and in dead-sperm and non-sperm cells in $50 \%$ and $30 \%$ of the samples respectively suggests that seminal plasma and nonsperm cells are more infected by HIV than spermatozoa. This finding may be related to the frequent presence of polymorphonuclear leukocytes in this fraction. These cells are considered a risk factor for excretion of HIV in semen, as they are related to inflammation and infection and involve other cells such as macrophages and lymphocytes, which are known to be HIV carriers ${ }^{8}$.

Our findings confirm the evidence of earlier studies, and in particular that carried out by KIM et al. ${ }^{18}$. While investigating the possibility of spermatozoa infection by HIV by means of specific receptors (CD4, CCR5, CXCR4), KIM et al. observed that the presence of the virus is limited to seminal plasma and nonsperm cells, and concluded that HIV does not target sperm cells.

In the post-semen washing phase, however, virus detection proved negative in all the fractions. The overall effectiveness of semen washing and Percoll ${ }^{\circledR}$ followed by swim-up observed in our results corroborates data from the literature, in which two methods were also used together to obtain sperm cells without viral particles ${ }^{8,17,18,32,41,43}$. The effectiveness of these techniques is complemented by molecular biology methods which are indispensable in assisted reproduction programs for serodiscordant couples ${ }^{14,19,42}$.

We conclude that semen washing, together with the relevant reproductive technology and HAART, reduce the risk of viral transmission. These findings lead us to believe that, although semen is rarely found to contain $\mathrm{HCV}$, semen purification is highly beneficial for $\mathrm{HIV} / \mathrm{HCV}$ coinfected individuals.

\section{RESUMO}

\section{Detecção do RNA do HIV e HCV em sêmen de homens brasileiros, usando PCR multiplex antes e depois do "semen washing"}

O aumento da sobrevida dos pacientes que utilizam terapêutica antiretroviral altamente eficaz (HAART- Highly Active Antiretroviral Therapy) trouxe uma nova demanda de casais sorodiscordantes que desejam filhos. Como esses casais não podem abandonar o uso de preservativos, torna-se indispensável tratar o sêmen infectado com técnicas laboratoriais eficazes que além de isolar os melhores espermatozóides, reduzam a carga viral do HIV e HCV a níveis indetectáveis.

Para isso, são utilizadas técnicas de semen washing, associadas a testes ultra sensíveis de biologia molecular. Após análise seminal, sêmen de 20 pacientes co-infectados HIV-HCV foram submetidos a fracionamento celular e isolamento de espermatozóides móveis através de método de densidade de gradiente descontínuo e swim-up. Posteriormente, testes para detecção do RNA do HIV e HCV foram aplicados nos sêmens totais e frações seminais obtidas. Em fase pré semen washing, o HIV foi detectado em $100 \%$ dos semens totais. Contrariamente, o HCV foi detectado em apenas uma amostra. Em fase pós semen washing, o HIV e HCV não foram detectados em nenhuma das frações seminais. A redução do HIV e do HCV através de semen washing mostra-se um método eficaz a indivíduos coinfectados HIV-HCV, apesar do encontro do HCV no sêmen ser raro.

\section{REFERENCES}

1. BACCETTI, B.; BENEDETTO, A.; BURRINI, A.G. et al. - HIV-particles in spermatozoa of patients with AIDS and their transfer into the oocyte. J. Cell Biol., 127: 903-914, 1994.

2. BACCETTI, B.; BENEDETTO, A.; COLLODEL, G. et al. - The debate on the presence of HIV-1 in human gametes. J. reprod. Immunol., 41: 41-67, 1998.

3. BANDIVDEKAR, A.H.; VELHAL, S.M. \& RAGHAVAN, V.P. - Identification of CD4independent HIV receptors on spermatozoa. Amer. J. reprod. Immunol., 50: 322 $327,2003$.

4. BELLO, G.; CASADO, C.; SANDONIS, V. et al. - A subset of human immunodeficiency virus type 1 long-term non-progressors is characterized by the unique presence of ancestral sequences in the viral population.C. J. gen. Virol., 86: 355-364, 2005.

5. BODSWORTH, N.J.; CUNNINGHAM, P.; KALDOR, J. \& DONOVAN,B. - Hepatitis $\mathrm{C}$ virus infection in a large cohort of homosexually active men: independent associations with HIV-1 infection and injecting drug use but not sexual behaviour. Genitourin. Med., 72: 118-122, 1996.

6. BROSTROM, C.; VISCO-COMANDINI, U.; YUN, Z. \& SONNERBORG, A. Longitudinal quantification of human immunodeficiency virus type 1 DNA and RNA in long-term nonprogressors. J. infect. Dis., 179: 1542-1548, 1999.

7. BUCHBINDER, S. \& VITTINGHOFF, E. - HIV-infected long-term nonprogressors: epidemiology, mechanisms of delayed progression, and clinical and research implications. Microbes Infect., 1 : 1113-1120, 1999. 


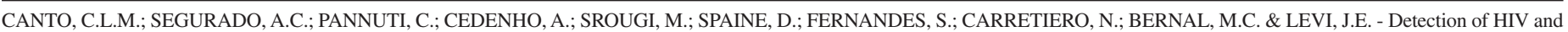
HCV RNA in semen from Brazilian coinfected men using multiplex PCR before and after semen washing. Rev. Inst. Med. trop. S. Paulo, 48(4): 201-206, 2006.

8. BUJAN, L.; DAUDIN, M.; MATSUDA, T. et al. - Factors of intermittent HIV-1 excretion in semen and efficiency of sperm processing in obtaining spermatozoa without HIV1 genomes. AIDS, 18: 757-766, 2004.

9. BRASIL. Ministério da Saúde - Carga viral. Brasília. Ministério da Saúde; Coordenação Nacional de Doenças Sexualmente Transmissíveis e AIDS, 1999.

10. den UYL, D.; van der HORST-BRUINSMA, I.E. \& van AGTMAEL, M. -Progression of HIV to AIDS: a protective role for HLA-B27? AIDS Rev., 6: 89-96, 2004.

11. DEVAUX, A.; SOULA, V.; SIFER, C. et al. - Hepatitis C virus detection in follicular fluid and culture media from $\mathrm{HCV}+$ women, and viral risk during IVF procedures. Hum. Reprod., 18: 2342-2349, 2003.

12. FILIPPINI, P.; COPPOLA, N.; SCOLASTICO, C. et al. - Does HIV infection favor the sexual transmission of hepatitis C? Sex. transm. Dis., 28: 725-729, 2001.

13. FIORE, R.J.; POTENZA, D.; MONNO, L. et al. - Detection of HCV RNA in serum and seminal fluid from HIV-1 co-infected intravenous drug addicts. J. med Virol., 46: 364-367, 1995.

14. GARRIDO, N.; MESEGUER, M.; BELLVER, J. et al. - Report of the results of a 2 year programme of sperm wash and ICSI treatment for human immunodeficiency virus and hepatitis C virus serodiscordant couples. Hum. Reprod., 19: 2581-2586, 2004.

15. GARRIDO, N.; MESEGUER, M.; SIMON, C.; PELLICER, A. \& REMOHI, H. - Assisted reproduction in $\mathrm{HIV}$ and $\mathrm{HCV}$ infected men of serodiscordant couples. Arch. Androl., 50: 105-111, 2004.

16. GUPTA, P.; LEROUX, C.; PATTERSON, B.K. et al. - Human immunodeficiency virus type 1 shedding pattern in semen correlates with the compartmentalization of viral Quasi species between blood and semen. J. infect. Dis., 182: 79-87, 2000

17. HANABUSA, H.; KUJI, N.; KATO, S. et al. - An evaluation of semen processing methods for eliminating HIV. AIDS, 14: 1611-1616, 2000.

18. KIM, L.U.; JOHNSON, M.R.; BARTON, S. et al. - Evaluation of sperm washing as a potential method of reducing HIV transmission in HIV - discordant couples wishing to have children. AIDS, 13: 645-651, 1999.

19. LERUEZ-VILLE, M.; ALMEIDA, M.; TACHET, A. et al. - Assisted reproduction in HIV-1-serodifferent couples: the need for viral validation of processed semen. AIDS, 16: $2267-2273,2002$.

20. LERUEZ-VILLE, M.; KUNSTMANN, J.M.; ALMEIDA, M.; ROUZIOUX, C. \& CHAIX, M.L. - Detection of hepatitis C virus in the semen of infected men. Lancet, 356 (9223): 42-43, 2000.

21. LEVY, R.; BOURLET, T.; MAERTENS, A. et al. - Pregnancy after safe IVF with hepatitis C virus RNA-positive sperm. Hum. Reprod., 17: 2650-2653, 2002.

22. LEVY, R.; TARDY, J.C.; BOURLET, T. et al. - Transmission risk of hepatitis C virus in assisted reproductive techniques. Hum. Reprod., 15: 810-816, 2000.

23. LIUZZI, G.; CHIRIANNI, A.; CLEMENTI, M. et al. - Analysis of HIV-1 load in blood, semen and saliva: evidence for different viral compartments in a cross-sectional and longitudinal study. AIDS, 10: 51-56, 1996.

24. MARINA, S.; MARINA, F.; ALCOLEA, R. et al. - Pregnancy following intracytoplasmic sperm injection from an HIV-1-seropositive man. Hum. Reprod., 13: 3247-3249, 1998.

25. MENDES-CORREA, M.C.; BARONE, A.A. \& GUASTINI, C. - Hepatitis C virus seroprevalence and risk factors among patients with HIV infection. Rev. Inst. Med. trop. S. Paulo, 43: 15-19, 2001.

26. MORTIMER, D. - Sperm preparation methods. J. Androl., 21: 357-366, 2000.

27. NAGAI, H.; WADA, K.; MORISHITA, T. et al. - New estimation method for highly sensitive quantitation of human immunodeficiency virus type 1 DNA and its application. J. virol. Meth., 124: 157-165, 2005.
28. NICOPOULLOS, J.D.; ALMEIDA, P.A.; RAMSAY, J.W. \& GILLING-SMITH, C. - The effect of human immunodeficiency virus on sperm parameters and the outcome of intrauterine insemination following sperm washing. Hum. Reprod., 19: 2289-2297, 2004 .

29. PALERMO, G.D.; COLOMBERO, L.T.; SCHATTMAN, G.L.; DAVIS, O.K. \& ROSENWAKS, Z. - Evolution of pregnancies and initial follow-up of newborns delivered after intracytoplasmic sperm injection. J. Amer. med Ass., 276: 18931897,1996

30. PALERMO, G.; JORIS, H.; DEVROEY, P. \& VAN STEIRTEGHEM, A.C. -Pregnancies after intracytoplasmic injection of single spermatozoon into an oocyte. Lancet., 340(8810): 17-18, 1992

31. PASQUIER, C.; BUJAN, L.; DAUDIN, M. et al. - Intermittent detection of hepatitis C virus $(\mathrm{HCV})$ in semen from men with human immunodeficiency virus type 1 (HIV1) and HCV. J. med. Virol., 69: 344-349, 2003.

32. PASQUIER, C.; DAUDIN, M.; RIGHI, L. et al. - Sperm washing and virus nucleic acid detection to reduce HIV and hepatitis $\mathrm{C}$ virus transmission in serodiscordant couples wishing to have children. AIDS, 14: 2093-2099, 2000.

33. PASSOS, E.P.; SILVEIRA, T.R.; SALAZAR, C.C. et al. - Hepatitis C virus infection and assisted reproduction. Hum. Reprod., 17: 2085-2088, 2002.

34. PEKLER, V.A.; ROBBINS, W.A.; NYAMATHI, A. et al. - Use of versant TMA and bDNA 3.0 assays to detect and quantify hepatitis $C$ virus in semen. J. clin. Lab. Anal., 17: 264-270, 2003.

35. PERSAUD, D.; SIBERRY, G.K.; AHONKHAI, A. et al. - Continued production of drugsensitive human immunodeficiency virus type 1 in children on combination antiretroviral therapy who have undetectable viral loads. J. Virol., 78: 968-979, 2004.

36. POTTER, S.J.; LEMEY, P.; ACHAZ, G. et al. - HIV-1 compartmentalization in diverse leukocyte populations during antiretroviral therapy. J. Leukoc. Biol., 76: 562-570, 2004.

37. PUDNEY, J.; NGUYEN, H.; XU, C. \& ANDERSON, D.J. - Microscopic evidence against HIV-1 infection of germ cells or attachment to sperm. J. Reprod. Immunol., 41: 105-125, 1998.

38. RESPESS, R.A.; BUTCHER, A.; WANG, H. et al. - Detection of genetically diverse human immunodeficiency virus type 1 group $\mathrm{M}$ and $\mathrm{O}$ isolates by PCR. J. clin. Microbiol., 35: 1284-1286, 1997.

39. ROCKSTROH, J.K. \& SPENGLER, U. - HIV and hepatitis C virus co-infection. Lancet infect. Dis., 4: 437-444, 2004.

40. SEGURADO, A.C.; BRAGA, P.; ETZEL, A. \& CARDOSO, M.R. - Hepatitis C virus coinfection in a cohort of HIV-infected individuals from Santos, Brazil: seroprevalence and associated factors. AIDS Patient Care STDS., 18: 135-143, 2004.

41. SEMPRINI, A.E.; FIORE, S. \& PARDI, G. - Reproductive counselling for HIVdiscordant couples. Lancet., 349(9062): 1401-1402, 1997.

42. SEMPRINI, A.E. \& FIORE, S. - HIV and reproduction. Curr. Opin. Obstet. Gynecol., 16: $257-262,2004$.

43. SEMPRINI, A.E.; LEVI-SETTI, P.; BOZZO, M. et al. - Insemination of HIV-negative women with processed semen of HIV-positive partners. Lancet., 340(8831): 13171319,1992 .

44. SHEPARD, R.N; SCHOCK, J.; ROBERTSON, K. et al. - Quantitation of human immunodeficiency virus type 1 RNA in different biological compartments. J. clin. Microbiol., 38: 1414-1418, 2000.

45. TERRAULT, N. - Motion - the available treatments for hepatitis C are cost effective: arguments for the motion. Canad. J. Gastroent., 16: 705-709, 2002. 
CANTO, C.L.M.; SEGURADO, A.C.; PANNUTI, C.; CEDENHO, A.; SROUGI, M.; SPAINE, D.; FERNANDES, S.; CARRETIERO, N.; BERNAL, M.C. \& LEVI, J.E. - Detection of HIV and HCV RNA in semen from Brazilian coinfected men using multiplex PCR before and after semen washing. Rev. Inst. Med. trop. S. Paulo, 48(4): 201-206, 2006.

46. VISCO-COMANDINI, U.; YUN, Z.; VAHLNE, A. \& SONNERBORG, A. - No association of HIV type 1 long terminal repeat sequence pattern with long-term nonprogression and in vivo viral replication levels in European subjects. AIDS Res. Hum. Retrovir., 15: 609-617, 1999.

47. WOITAS, R.P.; ROCKSTROH, J.K.; BEIER, I. et al. - Antigen-specific cytokine response to hepatitis $\mathrm{C}$ virus core epitopes in HIV/hepatitis $\mathrm{C}$ virus-coinfected patients. AIDS, 13: 1313-1322, 1999.

48. WORLD HEALTH ORGANIZATION - Manual for the examination of human semen and semen-cervical mucus interatio. 4. ed. Cambridge, Cambridge University Press, 1999.
49. ZANETTI, A.R.; TANZI, E.; PACCAGNINI, S. \& NEWELL M.L. - Mother-to-infant transmission of hepatitis C virus. J. Hepat., 31: 96-100, 1999.

50. ZANETTI, A.R.; TANZI, E.; PACCAGNINI, S. et al. - Mother-to-infant transmission of hepatitis C virus. Lombardy Study Group on Vertical HCV Transmission. Lancet, 345(8945): 289-291, 1995.

Received: 19 October 2005

Accepted: 20 April 2006 